\title{
ANALISA PENDAPATAN DAN EFISIENSI EKONOMIS PENGGUNAAN PAKAN PADA USAHATANI PENGGEMUKAN SAPI BALI (STUDI KASUS DI DESA LEBIH, KABUPATEN GIANYAR)
}

\author{
SUKANATA I W., SUCIANI, PARIMARTHA, K.W., \\ PUTRI, B. R. T., DAN SURANJAYA, I G. \\ FAKULTAS PETERNAKAN, UNIVERSITAS UDAYANA, DENPASAR-BALI \\ e-mail: nata_suka@yahoo.com
}

\begin{abstract}
ABSTRAK
Kemampuan petani untuk mengalokasikan faktor-faktor produksi secara efisien dan ekonomis sangat penting untuk memaksimumkan pendapatan. Penelitian ini bertujuan untuk menganalisis pendapatan peternak dan tingkat efisiensi ekonomis penggunaan pakan hijauan dan pakan konsentrat dalam usahatani penggemukan sapi bali. Wawancara terhadap 50 peternak yang ada di Desa Lebih telah dilakukan pada tahun 2009 untuk mengumpulkanan data. Tingkat pendapatan peternak dianalisis berdasarkan atas biaya tunai dan biaya total. Efisiensi ekonomis penggunaan pakan hijauan dan pakan konsentrat ditentukan dengan mencari indeks efisiensi pakan tersebut. Hasil penelitian ini menunjukkan bahwa usahatani penggemukan sapi bali memberikan keuntungan pada peternak sebesar Rp. 1.292.485/ekor, dengan R/C ratio 1,2 jika hanya memperhitungkan biaya tunai (tanpa memperhitungkan biaya pakan hijauan, tenaga kerja, dan lahan). Namun jika semua biaya diperhitungkan secara finansial, usahatani penggemukan sapi bali menyebabkan kerugian sebesar Rp. 698.426,65/ekor, dengan R/C rasio 0,92. Jumlah pemberian pakan hijauan sudah mendekati kondisi yang efisien secara ekonomis (sedikit berlebihan) dengan nilai Indeks Efisiensi 0,93. Sedangkan jumlah pemberian pakan konsentrat tidak efisien dengan nilai Indeks Efisiensi 0,57, pemberian pakan hijauan dan konsentrat harus dikurangi sehingga masing-masing menjadi 29,27 $\mathrm{kg} /$ ekor/hari dan 2,35 kg/ekor/hari (setara dedak padi) untuk mencapai kondisi yang efisien secara ekonomis.
\end{abstract}

Kata kunci: efisiensi ekonomis, pakan konsentrat, pakan hijauan, penggemukan sapi bali

\section{THE ANALYSIS OF FARMERS INCOME AND ECONOMIC EFFICIENCY USAGE OF GREEN FORAGE AND CONCENTRATE AS FEED FOR BALI CATTLE FEEDLOT}

\begin{abstract}
The ability of farmers to allocate production factors to be economically efficient is essential to maximize profits. This study was carried out to analyze farmers income and economic efficiency in the usage of green forage and concentrate as feed for bali cattle feedlot. Data collection was conducted through interview within 50 farmers at Lebih Village in 2009. In this study the income level of farmers was analyzed based on cash cost and total cost. Economic efficiency usage of green forage and concentrate feed were determined by the value of its Efficiency Index. The results showed that bali cattle feedlot were profitable for farmers, as of Rp. 1,292,485 per cattle and R/C ratio is 1.2 if considering on cash cost (without calculating cost of green forage feed, labor, and land). However, in case these cost also being calculated, so loss of Rp. 698,426.65 per cattle will be caused in the bali cattle feedlot within $\mathrm{R} / \mathrm{C}$ ratio 0.92. The amount of green forage feed usage was nearing economically efficient (slightly over), with the efficiency index of 0.93. Meanwhile, the amount of concentrate feed usage was not economically efficient within 0.57 efficiency index. The amount of green forage and concentrate feed usage should be reduced to $29.27 \mathrm{~kg}$ per cattle per day and $2.35 \mathrm{~kg}$ per cattle per day (equivalent to rice bran) respectively, so economic efficiency could be achieved.
\end{abstract}

Keywords: economic efficiency, concentrate feed, green forage feed, bali cattle feedlot 


\section{PENDAHULUAN}

Dilihat dari aspek pasar, pengembangan usaha penggemukan sapi potong mempunyai prospek yang sangat cerah. Daging sapi yang berasal dari peternakan sapi di Bali (sapi bali) sangat digemari oleh konsumen di luar Bali. Hal ini ditunjukkan oleh permintaan terhadap sapi potong yang terus meningkat dari tahun-ke tahun. Demikian tingginya permintaan tersebut, membuat kekhawatiran jika suatu saat populasi sapi di daerah ini akan terkuras, sehingga pemerintah membatasi perdagangan sapi ke luar Bali dengan sistem jatah. Permintaan dari luar Bali terhadap sapi potong yang diproduksi di Bali baru dapat dipenuhi sekitar 60\% karena kekurangan produksi. Pada periode 2001-2007 jumlah sapi potong yang dikirim ke luar Bali untuk di potong rata-rata 62.988 ekor/tahun, tumbuh rata-rata 9,5\%/tahun, (Dinas Peternakan Provinsi Bali, 2008).

Dalam rangka memenuhi permintaan yang begitu besar maka produksi harus ditingkatkan. Dalam berproduksi, pengalokasian faktor-faktor produksi harus dilakukan secara optimal, sehingga dapat memaksimumkan keuntungan. Salah satu faktor produksi yang penting bagi penggemukan sapi potong adalah pakan. Kesalahan dalam pengalokasian faktor produksi pakan dapat mengurangi keuntungan atau bahkan merugikan secara ekonomi bagi peternak, walaupun dapat memberikan penampilan produksi yang baik. Penelitian ini dilaksanakan untuk menganalisis pendapatan peternak dan tingkat efisiensi penggunaan pakan secara ekonomi. Hasil penelitian ini diharapkan dapat memberikan informasi bagi peternak maupun pemegang kebijakan untuk pengembangan peternakan sapi potong kearah yang lebih baik. Dengan demikian peternakan sapi potong dimasa depan akan lebih kompetitif dan dapat meningkatkan pendapatan peternak.

\section{METODE PENELITIAN}

Penelitian ini dilaksanakan dari bulan April hingga Nopember 2009 di Desa Lebih, Kecamatan Gianyar, Kabupaten Gianyar, Provinsi Bali. Sebanyak 50 orang peternak sapi penggemukan yang ditentukan secara acak telah diwawancarai dengan bantuan kuisioner. Wawancara terhadap beberapa key informan juga dilakukan untuk mengetahui persoalan usahatani penggemukan sapi potong di wilayah ini.

Analisis pendapatan dilakukan berdasarkan ratarata jumlah pemeliharaan sapi penggemukan di daerah penelitian (3 ekor) dengan rata-rata lama penggemukan 7 bulan. Pendapatan yang diperoleh dibedakan menjadi pendapatan atas biaya tunai dan pendapatan atas biaya total. Pendapatan atas biaya tunai dan atas biaya total ditentukan berdasarkan rumus (Soekartawi, 2003), yaitu:

$$
\begin{array}{ll}
\pi_{\mathrm{tn}}=\mathrm{NP}-\mathrm{BT}_{\mathrm{n}}, \text { dan } \pi_{\mathrm{tl}}=\mathrm{NP}-\mathrm{BT}_{\mathrm{l}}, \\
\text { dimana: } & \\
\pi_{\mathrm{tn}}= & \text { pendapatan atas biaya tunai (Rp) } \\
\pi_{\mathrm{tl}}= & \text { pendapatan atas biaya total (Rp) } \\
\mathrm{NP}= & \text { penerimaan (Rp) } \\
\mathrm{BT}_{\mathrm{n}}= & \text { biaya tunai }(\mathrm{Rp}) \\
\mathrm{BT}_{1}= & \text { Biaya total (Rp) }=\left(\mathrm{BT}_{\mathrm{n}}+\mathrm{BD}\right) \\
\mathrm{BD}= & \text { Biaya yang diperhitungkan }(\mathrm{Rp})
\end{array}
$$

Revenue Cost Ratio ( $R / C$ Ratio) dihitung dengan membagi penerimaan dengan biaya yang dikeluarkan. Biaya tunai merupakan biaya yang riil dikeluarkan oleh peternak untuk usaha penggemukan sapi. Sedangkan biaya yang diperhitungkan adalah biaya yang sesungguhnya tidak dikeluarkan oleh peternak untuk membeli suatu input produksi karena mereka dapat menghasilkan input tersebut namun diperhitungkan sebagai biaya. Biaya pakan hijauan, tenaga kerja, dan sewa lahan dikelompokkan ke dalam biaya yang diperhitungkan. Besarnya biaya tersebut diperhitungkan berdasarkan harga bayangan (shadow price). Selanjutnya biaya penyusutan ditentukan berdasarkan metode garis lurus (Ibrahim, 2003).

Efisiensi penggunaan pakan ditentukan dengan terlebih dahulu memformulasikan fungsi produksi sapi potong penggemukan ke dalam fungsi produksi CobbDouglas (Soekartawi, 2003) yang sudah ditransformasi kedalam bentuk log natural sebagai berikut:

$$
\begin{aligned}
& \ln \mathrm{Y}= \ln \mathrm{b}_{\mathrm{o}}+\mathrm{b}_{1} \ln \mathrm{X}_{1}+\mathrm{b}_{2} \ln \mathrm{X}_{2}+\mathrm{b}_{3} \ln \mathrm{X}_{3}+\mathrm{u} \\
& \text { dimana : } \\
& \mathrm{Y}=\text { produksi sapi potong }(\mathrm{kg}) \\
& \mathrm{b}_{\mathrm{o}}=\text { intersep } \\
& \mathrm{X}_{1}=\text { bibit/bakalan }(\mathrm{kg}) \\
& \mathrm{X}_{2}=\text { pakan hijauan }(\mathrm{kg}) \\
& \mathrm{X}_{3}=\text { pakan konsentrat }(\mathrm{kg}) \\
& \mathrm{b}_{\mathrm{i}}=\text { besaran parameter atau elastisitas faktor produksi } \\
& \quad \text { ke- } \mathrm{i}, \\
& \mathrm{u}=\text { disturbance term (residual) } \\
& \mathrm{e}=\text { bilangan natural }(2.781) \\
& \mathrm{i}= 1,2,3
\end{aligned}
$$

Pendugaan besaran parameter dilakukan dengan metode OLS (Ordinary Least Squares) melalui bantuan program komputer SAS (Statistical Analysis System) versi 9.1. Menurut Debertin (1986), profit akan maksimum ketika value of marginal product (VMP) sama dengan marginal factor cost (MFC). Berdasarkan hal ini maka pengujian tingkat efisiensi ekonomis penggunaan pakan hijauan dan pakan konsentrat dilakukan dengan menentukan nilai Indeks Efisiensi $\left(\mathrm{IE}_{\mathrm{i}}\right)$ dari masing-masing jenis pakan tersebut. Nilai $\mathrm{IE}_{\mathrm{i}}$ tersebut ditentukan dengan mencari rasio VMP dengan MFC dari masing-masing jenis pakan tersebut. MFC dari jenis pakan ke-i $\left(\mathrm{MFC}_{\mathrm{i}}\right)$ merupakan harga dari jenis pakan ke-i $\left(\mathrm{Px}_{\mathrm{i}}\right)$, sedangkan $V M P_{i}=P y M P_{i}$

dimana: 
VMPi = value of marginal product dari jenis pakan ke-i

Py = harga sapi potong

$\mathrm{MPi}=$ produk marjinal dari jenis pakan ke-i $=\frac{\partial Y}{\partial X_{i}}$

Jumlah penggunaan jenis pakan ke-i dikatakan efisien secara ekonomi jika $\mathrm{IE}_{\mathrm{i}}=1$. Jika $\mathrm{IE}_{\mathrm{i}}<1$ maka jumlah penggunaan jenis pakan ke-i perlu dikurangi karena sudah berlebihan, dan sebaliknya jika $\mathrm{IE}_{\mathrm{i}}>1$.

\section{HASIL DAN PEMBAHASAN}

\section{Pendapatan dari Usahatani Penggemukan Sapi Bali}

Peternakan sapi di Desa Lebih merupakan peternakan rakyat dengan rata-rata jumlah pemeliharaan sapi penggemukan sebanyak 3 ekor/peternak. Usahatani tersebut tidak memberikan keuntungan yang layak bagi peternak melainkan merugikan, jika semua pengorbanan peternak dalam berproduksi diperhitungkan secara finansial (Tabel 1). Perhitungan ini akan menyebabkan kerugian sebesar Rp. -2.095.280 dengan R/C rasio sebesar 0,92 . Artinya setiap rupiah biaya yang dikeluarkan (termasuk biaya yang diperhitungkan) untuk usahatani penggemukan sapi bali akan memberikan penerimaan hanya sebesar Rp. 0,92. Namun jika perhitungan pendapatan tersebut hanya didasari atas biaya tunai (biaya yang sesungguhnya dikeluarkan peternak), maka usaha ini memberikan keuntungan sebesar Rp. 3.877.455 (atau Rp. 1.292.485/ekor) dengan R/C ra- tio sebesar 1,2 artinya setiap rupiah biaya tunai yang dikeluarkan untuk usahatani penggemukan sapi potong akan memberikan penerimaan Rp. 1,2. Hasil penelitian ini sejalan dengan Yasa et al., (2007) yang menyatakan bahwa secara finansial dengan memperhitungkan semua biaya, penggemukan sapi potong di Desa Sanggalangit (Buleleng) merugikan petani. Namun demikian, ia menjelaskan bahwa petani tidak merasa rugi tapi malah merasa untung, karena secara riil tidak pernah mengeluarkan biaya untuk pembelian pakan hijauan, dan tenaga kerja, yang diperhitungkan sebagai biaya dalam analisis tersebut.

Sapi bakalan, pakan hijauan dan pakan konsentrat merupakan tiga komponen biaya yang sangat mempengaruhi pendapatan yang diperoleh peternak. Ratarata jumlah sapi yang dipelihara oleh peternak sebanyak 3 ekor dengan berat awal 228,33 kg/ekor. Rata-rata jumlah pemberian pakan konsentrat (setara dedak padi) sekitar 2,55 kg/ekor/hari, dan pemberian pakan hijauan sekitar 31,26 kg/ekor/hari. Pembelian bakalan merupakan biaya terbesar yang dikeluarkan oleh peternak, yaitu sekitar $62,15 \%$ dari biaya total, sedangkan biaya hijauan dan pakan konsentrat menempati urutan terbesar kedua dan ketiga dimana porsinya masing-masing sekitar 15,54\% dan 11,39\% dari biaya total.

Pemberian pakan dengan kualitas lebih tinggi belum tentu menguntungkan secara ekonomi bagi peternak walaupun dapat memberikan tampilan produksi yang lebih baik. Partama et al., (2009) menyatakan bahwa sapi

Tabel 1. Rata-Rata Pendapatan Usaha Penggemukan Sapi Potong di Desa Lebih per Periode Penggemukan (7 bulan)

\begin{tabular}{|c|c|c|c|c|c|c|c|}
\hline No & Uraian & Satuan & Jumlah fisik & $\begin{array}{c}\text { Harga (Rp/ } \\
\text { satuan) }\end{array}$ & Nilai (Rp) & $\%^{a}$ & $\%^{b}$ \\
\hline \multirow[t]{4}{*}{1} & Penerimaan: & & & & & & \\
\hline & Sapi ( 3 ekor) & $\mathrm{kg}$ & $1.044,36$ & 22.000 & 22.975 .863 & & \\
\hline & Pupuk Kandang & $\mathrm{kg}$ & 7.875 & 35,56 & 280.000 & & \\
\hline & Jumlah Penerimaan & & & & 23.255 .863 & & \\
\hline \multirow[t]{8}{*}{2} & Biaya Tunai: & & & & & & \\
\hline & Sapi Bakalan (3 ekor) & $\mathrm{kg}$ & 685,00 & 23.000 & 15.755 .000 & 81,30 & 62,15 \\
\hline & Pakan Konsentrat & $\mathrm{kg}$ & $1.604,54$ & 1.800 & 2.888 .172 & 14,90 & 11,39 \\
\hline & Obat-obatan & unit & 3,00 & 146.000 & 438.000 & 2,26 & 1,73 \\
\hline & Mineral & kg & 12,60 & 5.000 & 63.000 & 0,33 & 0,25 \\
\hline & Penyusutan kandang & $\mathrm{m}^{2}$ & 7,50 & 8.750 & 65.625 & 0,34 & 0,26 \\
\hline & Penyusutan Peralatan & $\mathrm{Rp}$ & & & 168.611 & 0,87 & 0,67 \\
\hline & Jumlah Biaya Tunai & & & & 19.378 .408 & & 76,44 \\
\hline \multirow[t]{5}{*}{3} & Biaya diperhitungkan: & & & & & & \\
\hline & Pakan Hijauan & kg & $19.693,80$ & 200 & 3.938 .760 & & 15,54 \\
\hline & Tenaga Kerja & HKSP & 79,36 & 25.000 & 1.983 .975 & & 7,83 \\
\hline & Sewa lahan area kandang & are & 0,50 & 100.000 & 50.000 & & 0,20 \\
\hline & Jumlah Biaya yang diperhitungkan & & & & 5.972 .735 & & 23,56 \\
\hline 4 & Biaya Total & & & & 25.351 .143 & & \\
\hline 5 & Pendapatan atas Biaya Tunai & & & & 3.877 .455 & & \\
\hline 6 & Pendapatan atas Biaya Total & & & & $(2.095 .280)$ & & \\
\hline 7 & $\mathrm{R} / \mathrm{C}$ ratio atas Biaya Tunai & & & & 1,20 & & \\
\hline 8 & $\mathrm{R} / \mathrm{C}$ ratio atas Biaya Total & & & & 0,92 & & \\
\hline
\end{tabular}

a dari biaya tunai, b dari biaya total

HKSP = Hari Kerja Setara Pria $=8 \mathrm{jam} /$ hari 
yang diberikan $5 \mathrm{~kg}$ konsentrat komersial (yang disuplementasi dengan vitamin-mineral $0,1 \%$ ) dan rumput gajah secara ad libitum mampu memberikan pertambahan berat badan yang cukup baik yaitu $0,66 \mathrm{~kg} / \mathrm{ekor} /$ hari (lebih tinggi dari rata-rata pencapaian peternak di daerah penelitian, yaitu 0,57 kg/ekor/hari). Namun jika kita perhitungkan secara finansial, pemberian pakan tersebut merugikan peternak dimana R/C-nya o,896 (berdasarkan biaya total) dan 0,986 (berdasarkan biaya tunai) yang diakibatkan oleh membengkaknya biaya pakan khususnya biaya pakan konsentrat.

Dari sisi produksi, untuk meningkatkan pendapatan peternak maka strategi penyediaan pakan dan bakalan yang berkualitas dengan harga yang layak sangat penting diperhatikan. Dalam hal penyediaan pakan, hasil penelitian ini menunjukkan bahwa pengembangan ternak sapi akan lebih menguntungkan jika dilakukan secara terintegrasi dengan tanaman (Crop-Beef Cattle System) dibandingkan dengan menggunakan pakan komersial. Melalui sistem integrasi tersebut, limbah pertanian dapat dimanfaatkan sebagai pakan ternak sehingga dapat menekan biaya produksi terutama biaya pakan. Hal ini sesuai dengan yang dinyatakan oleh Dwiyanto et al. (2002), dan Makka, (2004) yang pada intinya menyatakan bahwa peternakan sapi yang dilakukan secara terintegrasi dengan tanaman pertanian lebih menguntungkan karena dapat menekan biaya produksi. Implikasi dari hal ini adalah keberadaan lahan pertanian sebagai pendukung peternakan sapi harus dilindungi keberadaannya. Alih fungsi lahan pertanian ke non pertanian di Bali yang cukup tinggi, yaitu rata-rata 798 ha/ th (tahun 1997-2007) dapat mengancam perkembangan peternakan sapi di Bali. Hal ini perlu perhatian yang serius dari pemerintah untuk mengatasinya.

Sapi induk betina merupakan mesin biologis untuk menghasilkan anak sapi. Dengan demikian, untuk menunjang usahatani penggemukan maka populasi sapi induk betina harus ditingkatkan. Sukanata et al. (2009) menyatakan bahwa populasi sapi induk betina berpengaruh positif dan nyata secara statistik $(\mathrm{P}<0,05)$ terhadap produksi sapi di Bali dengan nilai elastisitas yang mendekati 1. Keberadaan sapi betina induk di Bali juga semakin penting dengan ditetapkannya daerah Bali sebagai daerah pemurnian sapi bali. Kebutuhan akan bibit sapi tentu hanya dapat dipenuhi dari produksi sendiri tanpa dapat mendatangkan bibit dari luar Bali. Berbagai upaya harus dipikirkan untuk dapat meningkatkan populasi sapi induk betina, beberapa diantaranya adalah pemberian insentif yang layak kepada peternak yang mau bergerak dibidang pengembangan sapi pembibitan (pemeliharaan induk), pencegahan penyelundupan sapi dari Bali ke luar dan pencegahan pemotongan betina produktif.
Tabel 2. Hasil Pendugaan Model

\begin{tabular}{lrrrc}
\hline \multicolumn{1}{c}{ Peubah } & $\begin{array}{r}\text { Parameter } \\
\text { Estimasi }\end{array}$ & $\begin{array}{c}\text { Standar } \\
\text { Error }\end{array}$ & $\operatorname{Pr}>|\mathrm{t}|$ & $\begin{array}{c}\text { Variance } \\
\text { Inflation }\end{array}$ \\
\hline Intersep & 0.163 & 0.26 & 0.5268 & 0 \\
$\operatorname{LnX}_{1}$ & 0.666 & 0.03 & $<0.0001$ & 3.71 \\
$\operatorname{LnX}_{2}$ & 0.161 & 0.04 & 0.0001 & 2.69 \\
$\operatorname{LnX}_{3}$ & 0.116 & 0.02 & $<0.0001$ & 2.95 \\
$\mathrm{R}^{2}=$ & 0.9874 & & & \\
$\operatorname{Pr}>\mathrm{F}=$ & $<0.0001$ & & & \\
\hline
\end{tabular}

\section{Model Produksi Sapi Potong di Desa Lebih}

Hubungan antara faktor-faktor produksi dengan produksi pada usahatani penggemukan sapi bali di Desa Lebih dapat dimodelkan ke dalam suatu fungsi produksi sebagai berikut: $\ln \mathrm{Y}=0,163+0,666 \ln \mathrm{X}_{1}+$ $0,161 \ln \mathrm{X}_{2}+0,116 \ln \mathrm{X}_{3}$

Berdasarkan hasil pendugaan model (Tabel 2), variabel bibit/bakalan, pakan hijauan, dan pakan konsentrat dapat menjelaskan dengan baik variasi dari produksi sapi penggemukan. Nilai elastisitas produksi terhadap perubahan jumlah penggunaan pakan hijauan dan pakan konsentrat masing-masing sebesar 0,161 dan 0,116 . Artinya setiap penambahan pemberian pakan hijauan sebesar 1\% akan meningkatkan produksi sebesar $0,161 \%$, dimana penggunaan faktor produksi lainnya tetap. Sedangkan setiap penambahan pemberian pakan konsentrat sebesar 1\% akan meningkatkan produksi sebesar 0,116\%, dimana penggunaan faktor produksi lainnya tetap. Elastisitas produksi yang positif dan besarnya antara nol dan satu menunjukkan bahwa peternak sapi di daerah penelitian sudah berproduksi pada kondisi yang rasional (Doll dan Orazem, 1984).

Jumlah nilai parameter estimasi dari semua peubah penjelas yang digunakan menunjukkan bahwa usahatani penggemukan sapi potong di Desa Lebih mendekati kondisi constant return to scale, dimana penambahan jumlah bibit, pakan hijauan, dan pakan konsentrat secara bersama-sama masing-masing sebesar $1 \%$ akan meningkatkan produksi sebesar 0,94\% (mendekati 1).

\section{Efisiensi Ekonomis Penggunaan Faktor Produksi}

Jumlah penggunaan faktor produksi bibit dan pakan hijauan pada daerah ini mendekati efisien secara ekonomis (sedikit berlebihan) yang ditunjukkan oleh nilai IE dari kedua faktor produksi tersebut yang mendekati 1, masing-masing sebesar 0,97 dan 0,93 (Tabel 3). Sedangkan jumlah penggunaan pakan konsentrat tidak efisien secara ekonomis (berlebihan), dimana nilai IEnya sebesar 0,57.

Pemberian pakan hijauan pada usahatani penggemukan di Desa Lebih sudah sedikit berlebihan dari pemberian optimalnya. Kondisi ini ditunjukkan oleh nilai IE-nya yang lebih kecil dari 1, yaitu sebesar 0,93, dimana VMP dan MFC-nya masing-masing sebesar 185,27 dan 200. Angka ini menunjukkan bahwa setiap 
Tabel 3. Rata-Rata Nilai Efisiensi Ekonomi dan Penggunaan Optimal Faktor Faktor Produksi pada Usahatani Penggemukan Sapi Potong

\begin{tabular}{lrrrrrr}
\hline $\begin{array}{c}\text { Faktor } \\
\text { Produksi }\end{array}$ & $\begin{array}{c}\text { Rata-rata } \\
\text { Input } \\
(\mathrm{kg})\end{array}$ & $\begin{array}{c}\text { Parameter } \\
\text { Estimasi }\end{array}$ & VMP & MFC & IE & $\begin{array}{c}\text { Penggu- } \\
\text { naan Opti- } \\
\text { mal }(\mathrm{kg})\end{array}$ \\
\hline Bibit & 685 & 0,666 & $22.349,98$ & 23,000 & 0,97 & 666 \\
Hijauan & 19,904 & 0,161 & 185,27 & 200 & 0,93 & 18,438 \\
Konsentrat & 2,611 & 0,116 & $1.021,08$ & 1,800 & 0,57 & 1,481 \\
\hline
\end{tabular}

penambahan pemberian pakan hijauan sebesar $1 \mathrm{~kg}$ dengan biaya $\mathrm{Rp} 200$ akan meningkatkan penerimaan petani hanya sebesar Rp. 185,27. Penggunaan pakan hijauan harus dikurangi menjadi 18,438 kg dalam satu masa penggemukan (atau 29,27 kg/ekor/hari) sehingga efisien secara ekonomis.

Nilai Indeks Efisiensi faktor produksi pakan konsentrat yaitu sebesar 0,57 dimana VMP dan MFC-nya masing-masing sebesar 1.021,08 dan 1.800. Hal ini berarti bahwa setiap penambahan pemberian pakan konsentrat sebesar $1 \mathrm{~kg}$ (setara dedak padi) dengan biaya Rp 1.800 akan meningkatkan penerimaan petani hanya sebesar Rp. 1.021,08. Angka tersebut menunjukkan bahwa pemberian pakan konsentrat sudah sangat berlebihan dari tingkat optimalnya. Dengan demikian maka pemberian pakan konsentrat harus dikurangi menjadi 1.481 $\mathrm{kg}$ dalam satu masa penggemukan (atau 2,35 kg/ekor/ hari setara dedak padi) untuk mencapai keadaan yang efisien secara ekonomis.

Dapat simpulkan bahwa (1) Usahatani penggemukan sapi bali di Desa Lebih memberikan pendapatan yang cukup besar bagi peternak yaitu sebesar sebesar Rp. 1.292.485/ekor dengan $\mathrm{R} / \mathrm{C}$ rasio sebesar 1,2 jika hanya memperhitungkan biaya tunai (tanpa memperhitungkan biaya pakan hijauan, tenaga kerja, dan biaya lahan). Namun jika biaya-biaya tersebut juga diperhitungkan secara finansial maka usaha ini menyebabkan kerugian sebesar Rp. 698.426,65 per ekor, dengan $\mathrm{R} / \mathrm{C}$ rasio sebesar 0,92. (2) Usahatani penggemukan sapi potong di Desa Lebih mendekati kondisi constant return to scale, dimana jumlah elastisitas dari faktor produksi sebesar o,94. (3) Jumlah pemberian pakan hijauan sudah mendekati kondisi yang efisien secara ekonomis (sedikit berlebihan) dengan nilai Indeks Efisiensi sebesar 0,93. Untuk mencapai keadaan yang efisien secara ekonomis maka pemberian pakan hijauan harus sedikit dikurangi sehingga menjadi 29,27 kg/ekor/hari. (4) Jumlah pemberian pakan konsentrat sudah berlebihan dari tingkat optimalnya dimana nilai Indeks Efisiensinya sebesar o,57 sehingga tidak efisien secara ekonomis. Untuk mencapai keadaan yang efisien secara ekonomis maka pemberian pakan konsentrat harus dikurangi sehingga menjadi 2,35 kg/ekor/hari setara dedak padi.

\section{Saran}

1. Pemeliharaan sapi secara terintegrasi dengan tanaman (crop-beef cattle system) sangat penting untuk terus dikembangkan sehingga dapat menekan biaya produksi (khususnya biaya pakan) sehingga akan lebih kompetitif dan lebih menguntungkan bagi petani.

2. Untuk menunjang sistem integrasi tanaman dengan sapi (crop-beef cattle system) dapat berjalan secara berkelanjutan, maka pencegahan alih fungsi lahan pertanian ke non pertanian sangat penting dilakukan secara tegas.

\section{UCAPAN TERIMAKASIH}

Melalui kesempatan ini kami mengucapkan terimakasih banyak kepada:

1. Bapak Rektor Unud yang telah mendanai penelitian ini melalui dana DIPA

2. Bapak Gd. Atmika beserta seluruh responden yang ada di Desa Lebih, dan semua pihak yang telah membantu kegiatan penelitian ini.

\section{DAFTAR PUSTAKA}

Dinas Peternakan Provinsi Bali. 2008. Informasi Data Peternakan Provinsi Bali Tahun 2008. Denpasar

Doll, S. P. dan Orazem, F.. 1984. Production Economic: Theory with Applications, John and Sons, Inc. New York.

Dwiyanto, K., Prawiradiputra, B.R. dan Lubis, D. 2002. Integrasi Tanaman-Ternak dalam Pengembangan Agribisnis yang Berdaya Saing, Berkelanjutan dan Berkerakyatan. Buletin Ilmu Peternakan Indonesia, Wartazoa, 12(1): 1-8.

Ibrahim, H.M.Y. 2003. Studi Kelayakan Bisnis. Rineka Cipta. Jakarta.

Makka, D. 2004. Prospek Pengembangan Sistem Integrasi Peternakan yang Berdaya Saing. Prosiding. Seminar Nasional Sistem Integrasi Tanaman-Ternak Pusat Penelitian dan Pengembangan Peternakan bekerjasama dengan Balai Pengkajian Teknologi Pertanian Bali dan Crop-Animal System Research Network (CASREN). Ditjen Bina Produksi Peternakan, Departemen Pertanian. Jakarta.

Soekartawi. 2003. Teori Ekonomi Produksi dengan Pokok Bahasan Analisis Fungsi Cobb Douglas. PT Raja Grafindo persada. Jakarta.

Partama, I. B. G., Oka Cakra, I G. L., Trisnadewi, A. A. A. S. 2009. Optimalisasi Sintesis Protein Mikroba Rumen Melalui Suplementasi Vitamin dan Mineral dalam Ransum Berbasis Rumput Raja untuk Meningkatkan Produktivitas Sapi Bali. Laporan Penelitian. Fakultas Peternakan, Universitas Udayana. Denpasar.

Sukanata, I W., Suciani, Kayana, I G.N., Budiartha, I W. 2009. Strategi Peningkatan Produksi Sapi Potong di Provinsi Bali dalam Menunjang Swasembada Daging Nasional. Laporan Penelitian. Fakultas Peternakan, Universitas Udayana. Denpasar.

Yasa, I.M.R. et. al. 2007. Desa Sanggalangit Kecamatan Gerokgak, Kabupaten Buleleng, Bali. Laporan Akhir Primatani. Balai Pengkajian Teknologi Pertanian. Bali. 